\title{
THE ORIGINS OF TURNUS, VERGILIAN INVENTION, AND AUGUSTAN ROME
}

\begin{abstract}
Summary: This article briefly surveys literary sources on the Rutulians and Turnus and finds them to have been neither particularly informative nor plentiful. In fashioning his portrait of Turnus and his people, Vergil exploited that dearth of information by countering it and adding details not found in the earlier traditions. His inventive portrait of the heritage of Turnus, which emphasizes ethnic diversity, creates several parallels between Turnus and Aeneas, and helps make him both a direct counterpart and formidable opponent to the Trojan hero. By making the two warriors more similar than different via their mixed Italian and Greek ancestry, Vergil homogenizes them to the ethnically complex population of Rome during the age of Augustus.
\end{abstract}

Key words: ethnicity, heritage, Rutulian, diversity, tradition

The historical underpinnings of Vergil's Rutulians present scholars with interesting considerations, namely because of the scarcity of informative sources. While Vergil was working with traditional material and using legendary accounts in constructing his narrative, the extant traditional material is particularly lacking in information about Turnus and the Rutulians. In what follows, I will present a brief survey of the details that writers both prior to and following Vergil preserve about the Rutuli generally and about Turnus specifically. The principal objective of this survey is to ascertain something about the general character of the Rutuli and whether or not they were Italian in origin. To conclude, I will offer some suggestions as to what Vergil's motivations in developing his portrait of Turnus may have been, and what ends they may have served.

\section{THE RUTULI IN THE ANCIENT SOURCES PREDATING VERGIL}

Details about the identity, customs, and origins of the Rutuli are so scanty as to offer a very incomplete portrait of this nation. Extant accounts agree that the Rutuli, along with the Latini, Etrusci and several other tribes, inhabited Italy when the Trojans arrived. 
The earliest extant source mentioning the Rutuli is Cato, as preserved by Servius, who records that there were connections between the Etrusci and the Rutuli as well as between the Latini and Rutuli. Cato tells us that the Trojans received land from Latinus, ${ }^{1}$ and that Turnus sought the help of Mezentius in the battle against the Latins and Trojans. ${ }^{2}$ In the Aeneid, however, Vergil reverses this situation, as he depicts Mezentius, after being exiled by his people, seeking refuge from Turnus (8. 492-493: ille inter caedem Rutulorum elapsus in agro / confugere et Turni defendier hospitis armis). Cato also mentions that Mezentius had exacted tribute from the Rutuli (as well as from the Latini), ${ }^{3}$ a circumstance that would base their relationship not on equality or alliance but rather Mezentius' dominance.

Varro, via Pliny, records this fact as well, although he represents it a mutually agreeable exchange. ${ }^{4}$ However, his account likewise attests to a connection between

${ }^{1}$ Servius ad Aen. 11. 316: Cato enim in Originibus dicit, Troianos a Latino accepisse agrum, qui est inter Laurentum et castra Troiana. hic etiam modum agri commemorat et dicit eum habuisse iugera IIDCC. For Cato (frg. 8) says in his Origines that the Trojans received the land which is between Laurentum and the Trojan Camp from Latinus. He also records the measurement of the area and says that it contained 698 acres. (All translations are my own.)

${ }^{2}$ Servius ad Aen. 1. 267: Licet superius historia sit narrata, tamen etiam secundum Catonem historiae hoc habet, fides: Aeneam cum patre ad Italiam venisse et propter inuasos agros contra Latinum Turnumque pugnasse, in quo proelio periit Latinus. Turnum postea ad Mezentium confugisse eiusque fretum auxilio bella renovasse, quibus Aeneas Turnusque pariter rapti sunt. migrasse postea in Ascanium et Mezentium bella, sed eos singulari certamine dimicasse. Although the history was told previously, still even according to Cato (frg. 9), the reliable part of the history contains this: that Aeneas came to Italy with his father and, because of an attack on the territory, fought against Latinus and Turnus, and that Latinus died in that battle. Then Turnus fled to Mezentius and, relying on his aid, rekindled the war, in which Aeneas and Turnus both died. Afterwards the wars shifted to Ascanius and Mezentius, but that they fought in single combat; Serv. ad Aen. 4. 620: Cato dixit, iuxta Laurolavinium cum Aeneae socii praedas agerent, proelium commissum, in quo Latinus occisus est, fugit Turnus: et Mezentii auxilio conparato renovavit proelium, quo victus quidem est ab Aenea ... Si veritatem historiae requiras, primo proelio interemptus Latinus est in acie. inde, ubi Turnus Aeneam vidit superiorem, Mezentii imploravit auxilium. Cato (frg. 10) said that, when the allies of Aeneas were pursuing spoils near Laurolavinium, the battle in which Latinus was killed had begun, and Turnus fled; and having secured the help of Mezentius, he renewed the fight, the one in which indeed he was defeated by Aeneas. If you should ask the truth of this account, in the first skirmish Latinus was killed on the line of battle. Then, when Turnus saw that Aeneas was the better fighter, he sought the help of Mezentius; Serv. ad Aen. 6. 760: Aeneas, ut Cato dixit, simulac venit in Italiam, Laviniam accepit uxorem. propter quod Turnus iratus tam in Latinum quam in Aenean bella suscepit a Mezentio impetratis auxiliis. As Cato (frg. 11) said, as soon as Aeneas came to Italy, he received Lavinia as his wife. Angry at this, Turnus undertook war as much against Latinus as against Aeneas, after he had obtained help from Mezentius.

${ }^{3}$ Macrob. Sat. 3. 5. 10: Veram huius contumacissimi nominis [Mezentii contemptoris deorum] causam in primo libro Originum Catonis diligens lector inveniet. ait enim Mezentium Rutulis imperasse, ut sibi offerrent quas dis primitias offerebant, et Latinos omnes similis imperii metu ita vovisse: 'Iuppiter, si tibi magis cordi est nos ea tibi dare potius quam Mezentio, uti nos victores facias.' In the first book of the Origines of Cato (frg. 12), the diligent reader will find the true reason for his very insolent title (Mezentius, despiser of the gods). For he says that Mezentius had ordered the Rutulians to give him the first fruits that they offered to the gods, and all the Latins made this pledge under threat of a similar command: 'Jupiter, if it is your desire that we give these things to you rather than to Mezentius, may you make us victorious.'

${ }^{4}$ Pliny NH 14. 14. 88: M. Varro auctor est Mezentium Etruriae regem auxilium Rutulis contra Latinos tulisse vini mercede quod tum in Latino agro fuisset. Varro is the source that Mezentius, king of 
the Rutuli and Etrusci that involves a request for assistance against the Latini. Thus these early writers mention only that the Rutuli had some kind of relationship, whether alliances or struggles for power, with either the Etrusci or the Latini. None of them record anything about the nature of the Rutuli as a people, or whether they resisted the Etruscan imposition of tribute as Cato says the Latins did.

Cicero mentions the Rutuli only briefly, in a passage referring to a time centuries after the Trojans' arrival in Italy (DRP 2. 3. 5). He praises Romulus for founding the city on the site of the seven hills and not locating it on the coastline or invading the land that belonged to the Rutuli and Aborigines. ${ }^{5}$ This may suggest that those nations would have been hostile, but Cicero does not state such a thing directly or describe the character of these peoples in any way. Thus, despite the details they provide, Cato, Varro and Cicero say nothing about the Rutuli as a people, nothing about their customs or origins. Cicero refers to the Rutuli and Aborigines in the same sentence but does not state that they were allied. Cato declares that the Aborigines and the Trojans together were called the Latini after the Trojans' arrival in Italy, ${ }^{6}$ which would suggest that the name Aborigines would have ceased being used; Cicero, however, refers to the Aborigines as contemporaries of Romulus, showing that the chronology of the nomenclature is inconsistent even among the ancient writers - that is to say that in his account, they were not yet known as Latini in Romulus' time. Sallust presumably follows the same source as Cato regarding the union of the Trojans and Aborigines but says nothing of the Rutuli. ${ }^{7}$ Cato also links the Volsci with the Abori-

Etruria, gave assistance to the Rutulians against the Latins in exchange for the wine that was in the Latin territory at that time.

${ }^{5}$ Cicero DRP 2. 3. 5: Qua gloria parta urbem auspicato condere et firmare dicitur primum cogitavisse rem publicam. urbi autem locum, quod est ei qui diuturnam rem publicam serere conatur diligentissime providendum, incredibili opportunitate delegit. neque enim ad mare admovit, quod ei fuit illa manu copiisque facillimum, ut in agrum Rutulorum Aboriginumque (-ve?) procederet, aut in ostio Tiberino, quem in locum multis post annis rex Ancus coloniam deduxit, urbem ipse conderet, sed hoc vir excellenti providentia sensit ac vidit, non esse opportunissimos situs maritimos urbibus eis quae ad spem diuturnitatis conderentur atque imperii, primum quod essent urbes maritimae non solum multis periculis oppositae sed etiam caecis. After having achieved this glorious deed, it is said that he first thought about founding a city, once the auspices had been taken, and establishing the republic. But the location of the city is a matter that must be attended to with great foresight and diligence by a person who is trying to foster an everlasting republic, and he made a choice with amazing propriety. For he did not go towards the sea, which was a very easy thing for him with his band and troops, to invade the land of the Rutulians and Aborigines, or he himself would have established the city at the mouth of the Tiber, where many years later king Ancus had led his colony; but this man of outstanding foresight understood and saw that the coastal sites were not the most advantageous for cities that would be founded in the hope of longevity or even empire, firstly because coastal cities are liable to not just many dangers but even to those which are unexpected.

${ }^{6}$ Serv. ad. Aen. 1. 6: Cato in Originibus hoc dicit, cuius auctoritatem Sallustius sequitur in bello Catilinae [c.6], primo Italiam tenuisse quosdam, qui appellabantur Aborigines. hos postea adventu Aeneae Phrygibus iunctos Latinos uno nomine nuncupatos. In his Bellum Catilinae, Sallust follows the authority of Cato, who states in his Origines that in the beginning, a certain people called 'Aborigines' possessed Italy. And after the arrival of Aeneas, they were joined with the Phrygians and all were known by the single name of 'Latins'.

${ }^{7}$ Sallust BC 1. 6. 1-2: Urbem Romam, sicuti ego accepi, condidere atque habuere initio Troiani, qui Aenea duce profugi sedibus incertis vagabantur, cumque iis Aborigines, genus hominum agreste, sine legibus, sine imperio, liberum atque solutum. Hi postquam in una moenia convenere, dispari genere, 
gines, ${ }^{8}$ and mentions the Rutuli elsewhere, ${ }^{9}$ but not in conjunction with the Aborigines. Thus, even in the ancient accounts whether the Rutuli were autochthonous Italians, and exactly what their relationships were with the Latini, Volsci or Etrusci remains unclear.

These uncertainties and discrepancies do nothing to foster a clear vision of who the Rutuli were and how they were either related to or allied with other Italian nations. Yet, Vergil subtly represents the marriage of Turnus and Lavinia as a political alliance between the Latini and the Rutuli which would allow Turnus to become the progenitor of a new nation. ${ }^{10}$ He also depicts some kind of alliance between the Etrusci and Rutuli, for he represents Mezentius as seeking refuge with Turnus. Since Vergil's account differs from other authors in these details, it seems reasonable to assert that he was not following a lost tradition but that he intentionally altered such specifics. His inventiveness generally has been widely observed; and while it would be difficult and risky to presume much about the rationale behind his apparently deliberate alteration of traditional accounts, it also seems sensible to suggest that there was indeed some kind of rationale behind his representations of relationships between various peoples living on the peninsula just as there was a purpose to his complex portrayal of character.

\section{THE RUTULI IN THE ANCIENT SOURCES FOLLOWING VERGIL}

Of writers whose accounts postdate the Aeneid, Livy preserves details that, for the most part, accord with the earlier writers rather than Vergil. ${ }^{11}$ Livy maintains that

dissimili lingua, alii alio more viventes, incredibile memoratu est, quam facile coaluerint: ita brevi multitudo dispersa atque vaga concordia civitas facta erat. As I have heard it, the Trojans, when Aeneas was their leader, wandered about as exiles settling in uncertain sites, founded and inhabited the city of Rome in its beginning; and along with them the Aborigines, a rustic race of men, lawless, without an official government, free and without any restraints. They later came together in a single settlement, though they differed in race and language, each of them living by different customs; it is amazing to recount how easily they assimilated: thus in a short time this unsettled and roaming throng became a state by virtue of their harmonious existence.

${ }^{8}$ Prisc. 5. $182 \mathrm{H}$ : Cato in I Originum: Agrum quem Volsci habuerunt, campestris plerus Aboriginum fuit. Cato (frg. 7) in (book) 1 of the Origines: The territory which the Volsci held was for the most part in the territory of the Aborigines.

${ }^{9}$ Cato frg. 12, n. 3 supra.

${ }^{10}$ Turnus, as the son of King Daunus and Venilia, the sister of Amata, was Amata's nephew, and therefore not a foreign enough husband in Latinus' opinion, with respect to the prophecy that Lavinia must wed a foreigner. Daunus is the King of the Rutulians, Aen. 12. 22. Servius ad Aen. 6. 90 records that Venilia was Amata's sister.

${ }^{11}$ Livy 1. 2: Bello deinde Aborigines Troianique simul petiti. Turnus rex Rutulorum, cui pacta Lavinia ante adventum Aeneae fuerat, praelatum sibi advenam aegre patiens simul Aeneae Latinoque bellum intulerat. Neutra acies laeta ex eo certamine abiit: victi Rutuli: victores Aborigines Troianique ducem Latinum amisere. Inde Turnus Rutulique diffisi rebus ad florentes opes Etruscorum Mezentiumque regem eorum confugiunt, qui Caere opulento tum oppido imperitans, iam inde ab initio minime laetus novae origine urbis et tum nimio plus quam satis tutum esset accolis rem Troianam crescere ratus, haud gravatim socia arma Rutulis iunxit. Aeneas adversus tanti belli terrorem ut animos Aboriginum sibi conciliaret nec sub eodem iure solum sed etiam nomine omnes essent, Latinos utramque gentem appellavit; nec deinde Aborigines Troianis studio ac fide erga regem Aeneam cessere. Fretusque his animis coale- 
Turnus sought the help of Mezentius, that Mezentius was not killed by Aeneas, and that Latinus was lost in the first battle, following either Cato or a source common with him - all details which conflict with the narrative of the Aeneid. He does, however, name Turnus as rex Rutulorum which would lend some authority to what the ancients considered to be his nationality. Even though Livy mentions the tribes of the Aborigines, later called Latini, and the Rutuli and Etrusci by name, he describes neither their origins nor their ancestry. In fact, none of the sources which might have been expected to provide even a slim sketch of the Rutuli as a nation, such as Strabo or Pliny, contains any general description at all. This absence of general information could suggest that the Rutuli were so well-known by all these writers that any general description was considered unnecessary. However, the opposite may be just as likely: that the Rutuli were somewhat obscure even to the Romans of Vergil's day, who recognized their name but had no clear image of them as a people. Interestingly, when Pliny lists the 53 tribes that vanished without a trace (interiere sine vestigiis, NH 3. 5. 68-70), the Rutuli do not appear on that list. Pliny mentions them only as one of the many tribes that inhabited Latium at some point in time (3. 5. 56).

Strabo's account is to the point and clear in naming tribes and their hostilities (5. 3. 2). The pertinent details he preserves include the following: 1) that the Aeci, the Volsci, Hernici, Aborigines and Rutuli all lived near the city of the (later) Romans at the time of the Trojan arrival; 2) that Aeneas arrived at Laurentum with both Anchises and Ascanius; 3) that Latinus allied with Aeneas and the Trojans against the Rutuli; 4) that Latinus perished in that war; and 5) that the victorius Aeneas became king and called his people the Latini. Thus, he maintains consistency with Cato and Livy in naming of the people of Latinus the Latini and recording that they were originally called the Aborigines.

Dionysius of Halicarnassus, who also postdates Vergil, presents some potentially confusing details. For example, he first calls Lavinia the daughter of Evander

scentium in dies magis duorum populorum Aeneas, quamquam tanta opibus Etruria erat ut iam non terras solum sed mare etiam per totam Italiae longitudinem ab Alpibus ad fretum Siculum fama nominis sui implesset, tamen cum moenibus bellum propulsare posset in aciem copias eduxit. Secundum inde proelium Latinis, Aeneae etiam ultimum operum mortalium fuit. Next the Aborigines and Trojans together were attacked. Turnus, king of the Rutuli, to whom Lavinia had been promised before the arrival of Aeneas, and insulted that a stranger had been preferred over him, made war on Aeneas and Latinus together. Neither side departed happily from that skirmish: the Rutuli were defeated: the Aborigines and Trojans were victorious but lost their leader Latinus. Then Turnus and the Rutuli, lacking confidence in their circumstances, fled to the flourishing resources of the Etruscans and their king Mezentius. He at that time was ruling over the wealthy town of Caere, and from the start was not at all happy at the birth of this new city, thought that the Trojan presence was growing far more than was safe enough for their neighbors and most willingly joined his forces with the Rutulians. Aeneas, faced with threat of such a great war, in order to reconcile himself to the minds of the Aborigines since they were not only under the same law but also were all of the same name, named both nations the Latini; and then the Aborigines withheld neither their zeal from the Trojans nor their loyalty toward their king Aeneas. Relying on the spirits of the two peoples who were growing together more day by day, Aeneas - although Etruria had such great resources that she had filled not only the lands but even the sea through the entire length of Italy from the Alps to the strait of Sicily with the fame of her name - nevertheless, since he was able to ward off the war from his fortifications, led his troops into battle. That was the second war for the Latins, and for Aeneas, the last of his deeds on earth. 
(not Latinus) and makes her Latinus' mother by Hercules rather than Faunus. Of the Rutuli he says little except that there were tensions between them and the Aborigines (1. 43). The principal difference in his account lies in the claim that the Aborigines were actually Greeks from the Peloponnesus (1.60), and that even the Trojans were originally Greeks too (1. 61-62). The fact that his ulterior motive seems to be to make everyone ultimately Greek makes his account highly questionable.

In accordance with other early sources, Dionysius avers that Latinus was killed in battle with the Rutuli, and that the Trojans received land from the Aborigines, established Lavinium, soon after changed their name and together with the Aborigines were called the Latini, after their king (1.45). Elsewhere (1. 57-59) he states that when Aeneas arrived in Italy, Latinus was already at war with the Rutuli; but after meeting Aeneas and striking an alliance with him, agreed to give the Trojans land in return for receiving assistance in the war against the Rutuli. It is here that Dionysius says that they built the town called Lavinium, after either Latinus' daughter (perhaps named after her grandmother? He does not say so) or Lavinia the daughter of Anius, a prophetess who had sailed with the Trojans from Delos. Thus he records conflicting details which again seem to reflect the notion that all those on the Italian peninsula were of Greek origin. However, despite the fact that the name Aborigines seems to indicate an autochthonous people, Dionysius, apparently creating a hybrid Latin and Greek word, claims that they were Greeks from the Peloponnesus (1. 60), whose name suggests that they were from the mountains ( $a b$ ö $\rho \circ)^{\text {) }}$.

There are two important details in Dionysius' account that raise questions. He claims that Cato thought the Aborigines had originally come from Greece many generations prior to the Trojan war (1.11); and although Dionysius admits that the truth is unclear, he goes on to say that he believes the Aborigines were a colony of Arcadians, since they were the first to cross the Ionian sea. This "fact" could arise from his desire to make the Romans ultimately Greek; yet, confirmation may be found in Vergil's representation of the Arcadians and Evander. He also records that Turnus (1. 64), whose name he spells "Tyrrhenus," was actually Amata's nephew who, in anger over Latinus' decision to betroth Lavinia to Aeneas, deserted the Aborigines and joined forces with the Rutuli, who had earlier revolted against Latinus. ${ }^{12} \mathrm{He}$ also states that Mezentius, king of the Tyrrhenians, fought with the Rutuli, believing his territory to be in danger. None of this helps establish the ethnic identity of Turnus. Sources do not make clear whether he was originally one of the Latini or Aborigines (as nephew of Amata) who emigrated to the Rutuli, or a native Rutulian. His name (Turnus could be a simplified spelling of Tyrrhenus) and his frequent association with Mezentius indicate a close relationship to or even origin among the Etruscans. He was, in some way or other, linked with all four of these nations.

It would seem evident from their name that Aborigines were considered indigenous. It is generally assumed that the Latini were as well, but the ancient (and even

\footnotetext{
${ }^{12}$ Servius (ad Aen. 7. 366) records that Amata and Venilia were sisters. As the wife of Daunus, king of Ardea, Venilia may be another example of a native Italian female who married a foreigner.
} 
modern) sources dispute whether the Etrusci were native to Italy. ${ }^{13}$ Whether or not the Rutuli were native to Italy or of foreign origin seems impossible to ascertain, given the discrepancies in the ancient sources. Varro's etymology (7.83) of rutilare, "to be red", may suggest that a physical description (applied by Latin speaking people) lies behind the name of the Rutuli, the "red-haired ones". ${ }^{14}$ If Varro's etymology is accurate, it could suggest that the tribe did indeed have Greek (e.g., Menelaus was "red-haired") or other (eastern?) European origins. Mackie points out that Vergil is the only source that attributes Argive heritage to Turnus, even though his name appears to be Etruscan. ${ }^{15}$ In the Enciclopedia Virgiliana, Ampolo notes that the suffix -ulus is often an ethnic indicator, ${ }^{16}$ that the names Rutelna and Rutilus occur in the Corpus Inscriptionum Etruscorum, and goes on to explain that Rutilus - "il nome individuale Rutilus è penetrato anche in etrusco" - is considered the source of the Roman gentilicium Rutulius. The potential significance of the name's etymology notwithstanding, a possible connection between the Rutuli and the Etrusci again seems likely given this linguistic linkage.

\section{TURNUS THE RUTULIAN (?)}

The difficulty of determining the ethnic heritage of Turnus, whether via his familial relationships and Argive ancestry, the significance of his name, or his apparent affinity to both the Latini and the Etrusci, is the central matter here. Indeed it seems that in the sources other than Vergil, Turnus' ethnicity - and even his relationship to Amata $^{17}$ - was not clear; what remains to be considered is whether Vergil maintained

${ }^{13}$ Two ancient traditions hold that the Etruscans were considered either an autochthonous people of Italy or had arrived there from western Turkey. Dionysius 1. 25-30 avers their indigenous roots in Italy; Herodotus 1.94 records the story (attributed to the Lydians) that they emigrated from Lydia, led by Tyrrhenus. D. BRIQUEL (Les Pélasges en Italie. Recherches sur l'histoire de la légende. Paris 1984) has argued that the story was a politically motivated fabrication, and archaeology points to an older presence than the supposed 6th century migration. However, it bears noting that there were different accounts among the ancients, and that the allegation of Greek origins, while ultimately questionable for the Etruscans, was certainly the case for other areas and tribes of Italy (e.g., Diomedes founding Argyrippa and Canusium, Philoctetes founding Petelia and Crimissa.)

${ }^{14}$ Varro 7. 83: Aurora dicitur ante solis ortum, ab eo quod ab igni solis tum aureo aer aurescit. Quod addit rutilare, est ab eodem colore: aurei enim rutili, et inde etiam mulieres valde rufae rutilae dictae. Aurora is named from the rising of the sun, from the fact that the air becomes golden from sun's fire, which is golden at that time. He [Accius] adds that "to grow red" is from the same color; for "rutili" are golden (haired), and thus even women who are deeply red-haired are called "rutilae".

${ }^{15}$ MACKIE, C. J. Turnus and his Ancestors. CQ 41 (1991) 264.

${ }^{16}$ C. AMPOLO ("Rutuli". In Enciclopedia Virgiliana. Roma 1984-1990, 619-620) says: "Il nome dei Rutuli mostra la terminazione in -ulus che aveva spesso un valore etnico, ma concide con rutilus, che significava 'rosso'." (620) "The name of the Rutuli bears the ending -ulus which frequently had an ethnic significance, but echoes 'rutilus', which means 'red'."

${ }^{17}$ A. LA PENNA ("Amata". Enciclopedia Virgiliana [n. 14] 125-128) reminds us of the alternate tradition that Turnus was Amata's cousin, not nephew (Dion. Hal. 1. 64. 2; Fab. Pic. fr. 1 P; Origo gent. Rom. 13. 5). 
the conflicting details in the sources themselves or exploited them to suit his own poetic purposes. What is clear is that Vergil emphasizes the Greek heritage of Turnus, from describing Io on his swordbelt ${ }^{18}$ to attributing the founding of the city of Ardea - the Rutulian stronghold - to Danae, ${ }^{19}$ whom he makes Turnus' ancestor. ${ }^{20}$ Although some scholars consider the story of Danae founding Ardea a Vergilian invention, Pliny also preserves it, ${ }^{21}$ but could be following Vergil. If the Greeks were indeed instrumental in the founding of Ardea and Turnus were a Rutulian (rather than a Latin), Vergil would have been highlighting Turnus' foreign, rather than native, ancestry. This is a significant matter, since what ultimately encourages Latinus to reject Turnus and adopt Aeneas as his future son-in-law is the fact that he is adhering to a prophecy that he must betroth Lavinia to a man of foreign ancestry (7. 255, externa ab sede).

Furthermore, the details of Turnus' character, heritage and circumstances become even more pointed when compared with those of Aeneas - which suggests that Vergil intentionally paralleled his portraits of these two men to produce a rather evenly-matched competition between them. Turnus' father Daunus is aged and a mortal like Anchises. His mother Venilia is known as a water-nymph - which is arguably a parallel to Achilles' mother Thetis, ${ }^{22}$ but also a counterpart to Venus, ${ }^{23}$ whose name hers echoes. It is interesting to note that in his discussion of gods whose

${ }^{18}$ Aen. 7. 789-792: at levem clipeum sublatis cornibus Io / auro insignibat, iam saetis obsita, iam bos, / argumentum ingens, et custos virginis Argus, / caelataque amnem fundens pater Inachus urna. But Io put the distinguishing mark on the light shield, Io with her horns raised up in gold, Io covered with bristles, already a cow, an enormous emblem, and Argus the maiden's guardian, and her father Inachus pouring the river water from an engraved urn.

${ }_{19}$ Aen. 7. 406-412: Postquam visa satis primos acuisse furores / consiliumque omnemque domum vertisse Latini, / protinus hinc fuscis tristis dea tollitur alis / audacis Rutuli ad muros, quam dicitur urbem / Acrisioneis Danae fundasse colonis / praecipiti delata Noto. locus Ardea quondam / dictus avis, et nunc magnum manet Ardea / nomen, sed fortuna fuit. After the sad goddess (Allecto) seemed to have sufficiently sharpened her initial rage and to have overturned the plan and the entire home of Latinus, immediately she raises herself on her dark wings toward the walls of the bold Rutulian, toward the city which Danae is said to have founded for the Acrisian colonists when she was borne away by a headlong south wind. The place was once called Ardea by our ancestors, and even now Ardea remains a great name, but her fortune is past.

${ }^{20}$ Turnus' family tree is not precisely clear from Vergil's scattered references, but Pilumnus is either his grandfather or great-grandfather. Vergil refers to him as parens at 9. 4 and 12. 83, avus - possibly meaning "ancestor" rather than "grandfather" - at 10. 76, and quartus pater at 10. 619. Servius suggests that this last and most specific term be considered the most accurate description of Pilumnus in Turnus' heritage. Danae is thus either his grandmother (Daunus' mother) or great-grandmother (Daunus' grandmother).

${ }^{21}$ Pliny NH 3. 56: Ardea a Danae Persei matre condita. MACKIE (Turnus [n. 15] 264) confirms that "The sources for Turnus, other thanVergil himself ... give no clue to his ancestry". Mackie considers Cato as well as Dionysius and Livy in this assertion.

${ }^{22}$ MACKIE (Turnus [n. 15] 263) observes this link (263); The brief discussion of Venilia by J. D. REED (Virgil's Gaze: Nation and Poetry in the Aeneid. Princeton UP 2009, 56) ignores this interesting parallel.

${ }^{23}$ If Venilia is indeed considered a doublet for Venus, this would make the Turnus-Aeneas conflict a parallel to Romulus and Remus fighting to win the privilege to found the new nation. I am indebted to Gaius Stern for this observation. 
names are derived from various bodies of water, Varro mentions a water nymph Velinia, whose name derives from the lake of Velinus. ${ }^{24}$ The closeness of Velinia and Venilia suggests that there could have been a transposition of letters at some point in either the oral or manuscript tradition. That Varro mentions Velinia in the company of Iuturna and Tiber could suggest that he is actually discussing Venilia in this passage. ${ }^{25}$ Although Aeneas had no sister to whom Iuturna would serve as a counterpart, her semi-divine status further asserts the divine association of Turnus' family members and could be construed as a parallel to Aeneas' half-sibling Cupid, whom Venus uses to ensure Aeneas' welcome by the Carthaginians (which could also be a parallel to Juturna's "helpful" nature, discussed below).

Further blurring Turnus' family tree is the fact that scholars consider Daunus to be a Vergilian invention. Russi calls him "a rather nebulous character ... whose image has not been ... marked by Vergil with precise traces", and later adds that he is "an invented character, so it seems, by Vergil, non only because he is never attested earlier, but above all because later Vergil continues to introduce him, from time to time, conforming always and only to his own representation, without any significant difference." ${ }^{26}$ Vergil makes Daunus Turnus' father and Pilumnus his ancestor, whether his grandfather or great-grandfather. ${ }^{27}$ This detailed genealogy of Turnus occurs nowhere in any of the extant sources either preceding or following the Aeneid. ${ }^{28}$ Indeed, there appears to be no tradition on which Vergil bases his depiction of Turnus' father; furthermore, all subsequent references to Daunus clearly refer either to Vergil's character or to the mythological king of Apulia. Whether or not Daunus was indeed a Vergilian invention, the important matter is that Vergil appears to be placing both Daunus and Turnus, through Pilumnus and Danae, within a mixed native Italian and

${ }^{24}$ Varro 5. 71: In contrariis diis, ab aquae lapsu lubrico lympha. Lympha Iuturna quae iuvaret: itaque multi aegroti propter id nomen hinc aquam petere solent. A fontibus et fluminibus ac ceteris aquis dei, ut Tiberinus ab Tiberi, et ab lacu Velini Velinia. In deities of the opposite type, lympha ("water nymph") comes from the slippery gliding of the water. The water nymph Juturna was she who assisted (from iuvare): and so many who are ill customarily seek water from this source because of this title. From springs and rivers and other kinds of water come the (the names of) gods, such as Tiberinus from the Tiber and Velinia from the Veline lake.

${ }^{25}$ R. G. KENT (Varro: De Lingua Latina. 2. vols. Harvard UP 1957, 69) makes this observation in a footnote on this passage.

${ }^{26}$ A. RUSSI: "Dauno”. In Enciclopedia Virgiliana (n. 14) 1002: "un personaggio piuttosto evanescente .... la cui immagine non è stata .... delineata da Virgilio con tratti decisi, and 1003: un personaggio inventato, come pare, da Virgilio, non solo perché non è mai attestato prima, ma soprattutto perchè dopo Virgilio continua a incontrarsi di tanto in tanto sempre e solo conformemente alla rappresentazione virgiliana, senza alcuna variante significativa." REED, who explores ramifications in different directions of Turnus' familial connections (e.g., Daunus, Iuturna, Venilia), (n. 20) 64 suggests that Vergil may have selected the name "Daunus" for various resonances with both Danae and Danaus/the Danaids.

${ }^{27}$ Servius ad Aen. 7. 372 \& 410. Servius 10. 619 tries to sort out Pilumnus' placement in Turnus' family tree by suggesting that the first two terms be understood as indicating "ancestor" and that quartus pater, being the most precise, be taken as the true indicator; he even goes so far as to hypothesize that perhaps Pilumnus was the name of a father and son, both ancestors of Turnus.

${ }^{28}$ MACKIE (Turnus [n. 15]) 264 provides a concise account of Turnus' heritage and its implications when compared to that of Aeneas and notes that Vergil is the sole source of Turnus' Argive ancestry. 
Greek heritage. The reality of this mixed heritage is that while Turnus has Argive roots, he is native enough to make him ineligible to fulfill the prophecy that Lavina must marry a man of non-Italian blood. Yet, Turnus' ancestry weaves together strands both native and foreign to Italy - which is ultimately what Aeneas' stock serves to do. The additional matter of his Etruscan-sounding name and his potential ties to that nation, given its uncertain origins, would add to either side of the heritage, native or foreign, depending on which side of the ancient perspective is brought to bear.

That Iuturna is Turnus' sister may also be a Vergilian invention. ${ }^{29}$ Although Varro's derivation of her name from iuvare is considered a folk etymology by many scholars, West suggests that Vergil may well have been familiar with it. ${ }^{30}$ She also proposes that some combination of the folk etymology and the presence of the -tursyllabus in Juturna and Turnus may have encouraged Vergil to make them brother and sister. Like Turnus, Juturna reflects diverse ethnic associations. Walde-Hoffman ${ }^{31}$ considers her name Etruscan; she was associated with the Dioscuri in the Forum (they watered their horses in Lacu Iuturnae), ${ }^{32}$ and a later tradition places her firmly on Italian soil as the daughter of Volturnus. ${ }^{33}$ Castellani points to the lack of evidence for a traditional account of her relationship with Turnus and states "It appears that no document or other evidence antedating the Aeneid connects the water nymph 'Juturna' with 'Turnus' the warrior prince." 34 This lends credence to the notion that Vergil exercised considerable freedom in creating a very complex portrait of Turnus's family and background, perhaps at least in part due to the dearth of traditional details. The branches of Turnus' and Juturna's family tree have multiple ethnic roots; they were linked as siblings by Vergil, and like another pair of siblings, Dido and Anna, they are unfortunate victims of Aeneas' fate. The many parallels involved between various pairs of characters, such as those between Aeneas and Turnus or Aeneas and Dido, suggest that Vergil developed his character portrayals in manners that evoked the similarities between those pairs. This method could have emerged as a device to aid in character construction or highlight the vicissitudes of fortune (when one character falls victim to the other). In the cases of Aeneas and Turnus, it could also have had the desirable effect of demonstrating the mixed heritage of the Mediterranean population at large.

${ }^{29}$ PAPAIOANNOU, S.: Juturna's Lament Revisited: the Anxieties of Identity, Survival and Epic Closure. Annual Scholarly Transactions of the School of Philosophy of the University of Athens 41 (2010) 213-227.

${ }^{30}$ WeST, G. S.: "Giuturna”. In EnciclopediaVirgiliana (n. 14) 764-767, here 765. See also WEST, G. S.: Vergil's Helpful Sisters: Anna and Juturna in the Aeneid. Vergilius 25 (1979)10-19. Serv. ad Aen. 12.139 also suggests the etymology, perhaps basing his understanding on Varro.

${ }^{31}$ WALDE, A.: Lateinisches Etymologisches Wörterbuch. 3. Auflage, bearb. bei J. B. HoffmANN. Heidelberg 1938, 734-735, cited in WEST: Giuturna (n. 28) 765.

${ }^{32}$ The Dioscuri were well-known as helper gods.

${ }^{33}$ According to Arnobius (3. 29), Juturna gave birth to Fontus by Janus, and her father was Volturnus. Even Servius (ad Aen.12.139) preserves some of the confusion by stating Iuturna inter proprios deos nymphas ponitur, which would seem to consider her a nymph in her own right and suggest that Vergil's attribution of her divinity as compensation for stolen virginity was indeed his invention.

${ }^{34}$ CAStellani, V.: Anna and Juturna in the Aeneid. Vergilius 33 (1987) 49-57, here 50, n. 3. 
As has been noted, Turnus shares certain parallels in heritage and familial circumstances with Aeneas. The matter of each character's mixed lineage, and the fact they involve shared ethnicities, is important. When Aeneas requests guidance in Book 3, he is told to seek his ancient mother (antiquam exquirite matrem. / hic domus Aeneae cunctis dominabitur oris. 3. 96-97; "seek out your ancient mother. Here the home of Aeneas will hold dominion over all shores."). This ancient mother turns out to be Italy, which, as the Penates later inform him, is the original home of Dardanus:

est locus, Hesperiam Grai cognomine dicunt, terra antiqua, potens armis atque ubere glaebae; Oenotri coluere viri; nunc fama minores Italiam dixisse ducis de nomine gentem. hae nobis propriae sedes, hinc Dardanus ortus Iasiusque pater, genus a quo principe nostrum. (3. 163-168)

There is a place, which the Greeks call "Hesperia," an ancient land, powerful in war and of rich soil; the Oenotrian men cultivated it; now their descendants have called the nation Italy after the name of its leader. This place is our proper home, for Dardanus was born here, as was his father Iasius, and from that leader, our race.

Dardanus was the son of Jupiter and Electra, and thus Aeneas' family tree, like that of Turnus, includes both a Greek and native Italian line.

In Virgil's Gaze: Nation and Poetry in the Aeneid, J. D. Reed discusses the portrayal of Turnus. Tracing Turnus' Greek lineage as well as his many parallels to Dido, Reed devotes much attention to Vergil's characterization of Turnus through feminine and foreign associations. He makes an excellent case for a portrayal that, to the alert reader, dooms Turnus from the start, and anticipates the fact that what Turnus will really lose in his battle with Aeneas is the chance to father a nation. ${ }^{35}$ Like Reed, I believe that through the complexity of ethnicities in Turnus' background, as well as through the casting of Turnus as the Other through several parallels to Dido and other figures, Vergil demonstrates great powers of invention.

Readers of the Aeneid have long been familiar with Vergil's adroitness in alluding to the Iliad, but a few remarks at this point will further illustrate his brilliant technique of fostering complexity in plot and characterization. In the Iliad, the Trojans are defending their home from Greek invaders; in the Aeneid, the Trojans are the invaders, and the Italian tribes are defending their homes. Aeneas is the linchpin in this reversal, having fought at Troy and now fighting again in Italy; but now he is the invader looking for a new home and it is Turnus who fights in defense of his home. The woman who will go to the victor, Lavinia, is nothing like the fully-developed Helen of the Iliad, but is a mere wraith of a figure, perhaps a Vergilian illustration of

${ }^{35}$ SMALL, S. G. P.: The Arms of Turnus. TAPA 90 (1959) 243-252 suggests that the images on Turnus' weapons, in addition to having Greek and Eastern associations, are signs illuminating his character that point to his "innermost deficiencies and foreshadows his ultimate doom" (245). 
the fact that, unlike the famous and unusual beauty over whom the Greeks and Achaeans fought, Lavinia is an indistinct notion of what the future will be, a symbol of the new nation that will emerge from the blending of various blood-lines, and representative (to the warriors) of the chance to father a nation. ${ }^{36}$ Even at the brief moments in the text where Vergil names Aeneas "another Paris" (7. 321) and Turnus "a second Achilles" (6.89), the reversals and tensions rise to the fore; these allusions are not to be passed over lightly, for they enhance Vergil's depiction of the complexity and strain that characterizes not only the legendary history of Rome but what she had become in Vergil's day: a city rich and varied in texture, a conglomerate of ethnicities not only in the actual physical population but also in customs and culture.

The layers of complexity with which Vergil deploys the Aeneas-Turnus conflict also warrant comment. Before the Sibyl calls Turnus "a second Achilles", Aeneas has already been compared to that great hero several times. Most notably, when Dido addresses Aeneas at 4. 365-367, she refutes his parentage and calls him "pitiless", echoing Patroclus (to Achilles) at Iliad 16. 33-35. Aeneas's actions in Aeneid 5 frequently parallel those of Achilles in Iliad 23 (the funeral games). Although the Trojans' behavior is often characterized as more pious and compassionate than that of the Greeks, on many occasions Aeneas' actions recall those of Odysseus and heighten his portrayal as a warrior worthy of Homeric and Greek status. ${ }^{37}$ Thus, when Vergil names Turnus "a second Achilles" not only does he portray Turnus as a fully viable rival for Aeneas, he underscores the similarities between the two men. In their subsequent battle scenes, both heroes are compared with the Greek heroes at various moments, a technique that allows Vergil to parallel Turnus and Aeneas not just in lineage, as discussed above, but also in ability, action and demeanor. Since Vergil has reversed and convoluted the depiction of invaders and defenders from the Iliad, there is no simple right or wrong side in this battle; Vergil does not allow his contemporary Romans to view themselves as being either entirely pious and upright in their history any more than he allows them to consider their lineage as pure. Thus, Vergil takes pains to create Turnus as a foe who is in many ways a worthy rival, an equal to Aeneas. Only by defeating such a rival can Aeneas rise to bona fide heroic status, for there is no glory in defeating someone who is too weak to be a formidable opponent. But through the complexity of ethnic diversity, Vergil adds a more important element. In what may appear to be a paradoxical move, by creating such a nexus of parallels between Aeneas and Turnus, Vergil makes them both more generally human and less distinctly associated with any particular group; in other words, a complex ethnic heritage actually makes ethnicity less distinct, more nebulous, and therefore less signifi-

${ }^{36} \operatorname{REED}($ n. 23) 55.

${ }^{37}$ Such parallels have long been noted by scholars; a few important examples include OTIS, B.: Virgil: A Study in Civilized Poetry. Oxford UP 1964, esp. chapter VI "The Odyssean Aeneid", 215-312; Anderson, W. S.: The Art of the Aeneid. Prentice Hall 1969; MACKIE, C. J.: The Characterisation of Aeneas. Scottish Academic Press 1988. For a convenient list of parallels, see also QUARTARONE, L. N.: Appendix A: Homeric Parallels. In ANDERSON, W. S. - QuARTARONE, L. N. (eds.): Approaches to Teaching Vergil's Aeneid [MLA Approaches to Teaching World Literature] 2002, 201-224. 
cant. By associating Turnus with not only women but also other nations, Vergil creates at once a heroic figure who shares traits with the great Homeric heroes, including Aeneas himself, and any number of people on the Italian peninsula of mixed or indistinct lineage. At the same time, it bears noting that the contrasting images on the arms each fighter bears signify what they stand for: Turnus and his emblems of the mythic past are defeated by Aeneas, whose weapons depict the historical future. In this way, Vergil makes their battle one of a triumph for the future of Rome while simultaneously casting no single ethnic group as the adversary - in other words, Aeneas the Trojan is not finally and deservedly defeating the Greek Turnus. Through this young man so imperfect and complex, who loses the chance not only to marry but to father a nation, Vergil presents his audience with someone who, like Aeneas himself, is capable of both pietas and impietas, and whose closest Homeric counterpart is Hector. This is one way in which Turnus elicits compassion. Like even the great heroes of legend, we are all, in the end, imperfect and complex, from our heritage down to our actions; and it is a testament to Vergil's genius that he compels us to feel sympathy for characters who, in any other authors' pages, would not move us so profoundly.

\section{CONCLUSION: CREATIVITY AND MOTIVATION}

I suggest that Vergil fashioned his portrait of the Rutuli generally and Turnus specifically by exploiting a lack of detailed informational sources or, as the limited extant sources evince, deliberately contradicting some of the accounts to which he had access. In order to create a portrait of Turnus that suited his purposes, Vergil pointedly mirrors in Turnus both the traits and heritage of his rival Aeneas, thus making him both a direct counterpart and formidable opponent. Importantly, the mixed Italian and Greek heritage that both men share likely reflects the complex composition of much of the population of Rome during the age of Augustus. ${ }^{38}$ The effects of Turnus' complex ethnicity would make it easy to create sympathy for Turnus, not only because he is so much like Aeneas, but also because much of Vergil's contemporary population would find some common heritage or qualities with him. This portrayal would ideally produce a feeling of kinship and unity among the ethnically diverse members of the newly created empire. It seems reasonable to assert that Vergil, having lived through so much warfare, was well aware of the dangers of civil war and thus may have been inspired - or easily persuaded - to promote a view of the homogeneity among his contemporary Romans. And while it is true that presuming anything about authorial intent is not the best way to read any author, in this case, it seems logi-

${ }^{38}$ L. ADAMS HOLLAND (Place Names and Heroes in the Aeneid. AJP 56.3 [1935] 202-215) finds that the plethora of place names and eponymous figures found in the poem covers the whole of the peninsula, allowing readers to see themselves in the poem and connect to it. Interestingly, C. SAUNDERS (Sources of the Names of Trojans and Latins in Vergil's Aeneid. TAPA 71 [1940] 537-555) traces ninety percent of the Trojan and Latin names found in the Aeneid back to the Homeric poems. 
cal to acknowledge that the multiple ethnicities that lie behind both Turnus and Aeneas would have required a conscious effort and pointed manipulation of the legendary and historical sources on Vergil's part, and that that effort must have had a positive intention.

Lorina Quartarone

The University of Saint Thomas

lnquartarone@stthomas.edu 